\title{
Maturidade e suficiência
}

\section{Maturity and sufficiency}

\section{Madurez y suficiencia}

Mais uma vez, Ligia Bahia nos brinda com reflexões agudas, documentadas, instigantes e sempre com uma boa dose de provocação para estimular o debate. Trinta anos seria um bom tempo para uma "suficiente" "transição" de um sistema de saúde? De que situação original para que situação "suficiente"?

Penso, que se o marco do aniversário é a Constituição Federal de 1988, a "suficiência” seria o grau de alcance dos dispositivos que regem o ordenamento do setor saúde. A começar pelo Artigo 194 que estabelece a "Seguridade Social (...) que compreende um conjunto integrado de ações de iniciativa dos poderes públicos e da sociedade, destinadas a assegurar os direitos relativos à saúde, à previdência e à assistência social”. Complementada pela norma "mater" da saúde expressa no Artigo 196 com sua tríplice disposição: (i) saúde como direito de todos e dever do Estado; (ii) sua garantia por meio de políticas sociais e econômicas que reduzam o adoecimento e o sofrimento; e (iii) pelo acesso universal e igualitário às ações e serviços de saúde. Uma brevíssima recapitulação histórica nos ajudará a esclarecer.

A heterogeneidade das forças que levaram o regime militar à derrota e à assimetria de suas capacidades de intervenção e negociação políticas resultou numa Constituição em que foi possível a afirmação de direitos políticos fundamentais e concessões na declaração de direitos sociais, de tal forma que a matriz econômica fosse preservada. Entretanto, esse arranjo começou a ser corroído no momento seguinte de sua promulgação, quando o Presidente José Sarney promoveu a reforma ministerial, afastando a centro-esquerda de seu governo e erodindo a base política que se expressava em torno de Ulysses Guimarães.

A partir dali, teve início o processo de desconstrução e retrocesso do ordenamento da Seguridade Social e da Saúde. O primeiro passo foi consumado com a transferência do Instituto Nacional de Assistência Médica da Previdência Social (Inamps) para o Ministério da Saúde, afastando-o da organicidade tributária que se expressara na fixação de contribuições específicas para o financiamento da seguridade, e se radicalizou com a sua extinção, uma das poucas burocracias governamentais criadas com base na inspiração trabalhista 1,2 .

A promulgação da Lei no 8.080 em pleno início da vertigem neoliberal da época pode parecer paradoxal. Entretanto, seria útil salientar dois aspectos que terão relevância para a conformação do sistema
1 Instituto de Comunicação Científica e Tecnológica em Saúde, Fudação Oswaldo Cruz, Rio de Janeiro, Brasil.

Correspondência

J. C. Noronha

Laboratório de Informações em Saúde, Instituto de Comunicação Científica e Tecnológica em Saúde, Fudação Oswaldo Cruz. Av. Brasil 4365, Rio de Janeiro, RJ 21040-900, Brasil.

jose.noronha@icict.fiocruz.br 
de saúde brasileiro nos anos seguintes. O primeiro, de caráter normativo, em que a Lei reafirma o denominado Sistema Único de Saúde, SUS, não como universal, mas como explicita em seu Artigo 4o apenas o "O conjunto de ações e serviços de saúde, prestados por órgãos e instituições públicas federais, estaduais e municipais, da Administração direta e indireta e das fundações mantidas pelo Poder Público, constitui o Sistema Único de Saúde (SUS)”. A iniciativa privada, cuja liberdade de atuação é garantida pelo Artigo 199 da Constituição, só é abarcada pelo SUS na prestação de serviços ao mesmo (§ 2o do Artigo 4o, Lei no 8.080). Outro aspecto, em sentido oposto, diz respeito à preservação dos princípios declaratórios do direito à saúde e da sustentação da política de descentralização pela municipalização. A expansão do sufrágio universal, a despeito de todas as suas distorções, mantém a obrigatoriedade de atender, pelas lideranças políticas legislativas e executivas, às demandas, ainda que de formas denominadas por alguns de "clientelistas", por serviços de saúde da população não coberta por planos de saúde.

A Emenda Constitucional (EC) no 29/2000 rompeu a dedicação de contribuições sociais à Saúde, fixando seu crescimento a variações do produto interno bruto (PIB), quebrando o financiamento solidário da seguridade. A contração de recursos foi agravada com a breve vigência da EC 86/2015 que fixou os recursos como proporções da receita líquida, culminando com o congelamento dos gastos por 20 anos com a EC 95/2016.

Se a norma não define necessariamente a política, ela expressa as tensões das forças em disputa na sociedade. Trinta anos passados, o cumprimento Artigo 196 foi se distanciando, com flutuações de ênfase em seu tríplice mandamento. Apenas no período de 2003 a 2011, políticas sociais e econômicas tiveram impacto significativo na saúde das pessoas, conjugadas com a ampliação do acesso a serviços básicos como aqueles propiciados pela estratégia do programa de saúde da família. Mas não conquistou base política suficiente para conter o desmonte agressivo e as políticas regressivas e recessivas iniciadas em 2014 e agravadas depois do golpe institucional de 2016.

É na fragmentação política para a sustentação de um sistema público e universal, potencializada por avanço agressivo das forças liberais que debilitam o atendimento das necessidades dos grupos mais vulneráveis, que é adubado o terreno para o crescimento dos arranjos privados de prestação de cuidados de saúde. O Brasil, 30 anos depois de sua Constituição Cidadã, assiste a uma segmentação sem precedentes das políticas públicas, como a de saúde, que vai gerando uma administração à parte para as camadas mais ricas da sociedade, como nos aponta Souza ${ }^{3}$. Apesar das interseções e complementariedades apontadas no texto de Bahia, a prestação de cuidados intermediados por planos privados de saúde pode ser compreendida como um sistema à parte, múltiplo e fortemente estratificado, ordenado por uma agência reguladora atípica em seu mandato e denominação, a Agência Nacional de Saúde Suplementar (ANS), como nos assinala Menicucci 4.

A privatização setorial decorreu principalmente de políticas econômicas articuladas com a concessão de benefícios e tributos. Houve uma clara mudança de status das empresas privadas de assistência médica a partir dos anos oitenta, refletindo uma tendência internacional que localizava espaço para o mercado e o lucro no fracasso dos serviços públicos. Ocorreu uma estratégia de mudanças do regime de subsídios diretos para o de políticas fiscais de incentivos de demanda e de oferta, que protegeu as empresas na crise de recessão econômica do final dos anos noventa. Essa engrenagem permitiu ganhar a adesão de empregadores e empregados, estabelecendo uma conjugação de bases dos financiamentos e incentivos oriundos do fundo público, modelando uma assistência fragmentada e estratificada na sociedade e no interior das próprias empresas, como chama a atenção Bahia 5 .

Durante os 30 anos, houve ensaios fugazes para uma "transição suficiente" na direção dos ordenamentos constitucionais. Neste aniversário, o país assiste ao regresso acelerado à barbárie e, como nos diz Bahia, a um momento em que as "Forças politicas de centro-direita e os empresários do setor de assistência à saúde, sem apoio de movimentos sociais, oferecem a ampliação de seus mercados como projeto para o sistema de saúde, na prática um impiedoso modelo de segregação social”. 
1. Machado CV. Direito universal, política nacional: o papel do Ministério da Saúde na política de saúde brasileira de 1990 a 2002. Rio de Janeiro: Editora do Museu da República; 2007.

2. Costa AM, Noronha JC, Noronha GS. Barreiras ao universalismo do sistema de saúde brasileiro. In: Tetelboin C, Laurell AC, organizadores. Por el derecho universal a la salud: una agenda latinoamericana de análisis y lucha. Buenos Aires: Consejo Latinoamericano de Ciencias Sociales; 2015. p. 17-39.

3. Souza J. A elite do atraso: da escravidão à lava jato. Rio de Janeiro: Leya; 2017.
4. Menicucci TMG. Público e privado na política de assistência à saúde no Brasil: atores, processos e trajetórias. Rio de Janeiro: Editora Fiocruz; 2007. p. 233-89.

5. Bahia L. Financeirização e restrição de coberturas: estratégias recentes de expansão das empresas de planos e seguros de saúde no Brasil. In: Cohn A, organizadora. Saúde, cidadania e desenvolvimento. Rio de Janeiro: Centro Internacional Celso Furtado; 2013. p. 65-90. 